\title{
Physical Quantity Data Type
}

National Cancer Institute

\section{Source}

National Cancer Institute. Physical Quantity Data Type. NCI Thesaurus. Code $C 95673$.

A data type comprised of the amount or total number of a measured entity. 